\title{
PENGARUH RETURN ON ASSETS, CURRENT RATIO, TOTAL ASSET TURN OVER, DAN QUICK RATIO TERHADAP EARNING PER SHARE SERTA DAMPAKNYA TERHADAP DIVIDEND PAYOUT RATIO (Studi Kasus Pada Perusahaan Jasa Konstruksi Yang Terdaftar Di Bursa Efek Tiongkok)
}

\author{
Wirawan Suryanto*)
}

1) dosen dan mahasiwa universitas pamulang, email : wirawansuryanto@gmail.com

\section{ARTICLES}

\section{JURNAL SEKURITAS}

(Saham, Ekonomi, Keuangan dan Investasi )

Vol.2, No.3, Mei 2019

Halaman : $117-129$

(c) LPPM \& Prodi Manajemen

UNVERSITAS PAMULANG

ISSN (online) : 2581-2777

ISSN (print) : :2581-2696

\section{Keyword:}

Credit, CAR, NPL, Interest income and $\mathrm{ROA}$

JEL. classification :

C33, G21, G24, N15, N25

\section{Contact Author :}

PRODI MANAJEMEN UNPAM

JL.Surya Kencana No.1 Pamulang

Tangerang Selatan - Banten

Telp. (021) 7412566, Fax (021) 7412491

Email :

jurnalfinance.unpam@gmail.com
Penelitian ini dilakukan dengan tujuan untuk mengetahui pengaruh return on assets, current ratio, total asset turnover, dan quick ratio terhadap earning per share serta dampaknya terhadap dividend payout ratio (studi kasus pada perusahaan jasa konstruksi yang terdaftar di bursa efek tiongkok).

Penelitian ini menggunakan metode asosiatif kausal analisis. Data yang digunakan adalah data keuangan yang di terbitkan oleh masing masing perusahaan pada website perusahaan. Data pendukung penelitian ini diambil dari beberapa literature, seperti buku, website dan jurnal.

Hasil penelitian ini menyatakan bahwa : (1) return on assets berpengaruh secara signifikan terhadap earning per share, (2) current ratio tidak berpengaruh secara signifikan terhadap earning per share, (3) total asset turn over berpengaruh secara signifikan terhadap earning per share, (4) quick ratio berpengaruh secara signifikan terhadap earning per share. (5) Secara simultan return on assets, current ratio, total asset turn over, dan quick ratio berpengaruh secara signifikan terhadap earning per share.

The purpose of this research is to know the effect of return on assets, current ratio, total asset turnover, and quick ratio to earnings per share and its impact on dividend payout ratio (case study on construction service company listed in Chinese stock exchange).

This research uses associative methods of causal analysis. The data used are financial data published by each company on the company website. The supporting data of this research are taken from several literatures, such as books, websites and journals.

The results of this study states that: (1) return on assets has a significant effect on earnings per share, (2) current ratio does not significantly affect earnings per share, (3) total asset turnover significantly influence earnings per share, (4) quick ratio significantly influence earnings per share. (5) Simultaneously return on assets, current ratio, total asset turn over, and quick ratio significantly influence earnings per share 


\section{A. Pendahuluan}

Pada umumnya suatu perusahaan didirikan dengan tujuan untuk memperoleh laba, meningkatkan nilai perusahaan, dan memakmurkan pemegang saham serta memiliki kinerja yang konsisten selama perusahaan tersebut berdiri. Laba merupakan hasil dari usaha yang dilakukan oleh perusahaan pada suatu periode tertentu yang menghasilkan keuntungan bagi perusahaan tersebut. Laba tersebut tidak hanya dimanfaatkan bagi perusahaan semata, namun dapat juga di gunakan untuk memakmurkan pemegang saham. Laba adalah salah satu tolak ukur dari keberhasilan suatu perusahaan. Selain laba tingkat kemakmuran dari para pemegang saham dan kinerja yang konsisten juga termasuk dalam indikator keberhasilan suatu perusahaan.

Keberhasilan sebuah perusahaan dapat dilihat dari hasil kinerja keuangan yang dihasilkan selama suatu periode tertentu, informasi mengenai kinerja keuangan memiliki peranan yang penting juga sangat di perlukan oleh masyarakat luas umumnya, khususnya bagi calon investor. Investor dan masyarakat dapat mengukur keberhasilan dan kinerja dari suatu perusahaan pada suatu masa melalui hasil dari laporan keuangan yang di umumkan oleh perusahaat yang telah melakukan initial Public Offering. "Setelah perusahaan go public dan mencatatkan efeknya di bursa, maka emiten sebagai perusahaan publik wajib menyampaikan lapporan secara rutin maupun laporan lain jika ada kejadian penting kepada BAPEPAM dan BEI. Seluruh laporan yang disampaikan kepada bursa akan dipublikasikan oleh bursa kepada masyarakat pemodal melalui pengumuman dilantai bursa" (Rusidin, 2008:94).

Dalam perusahaan yang dapat menggambarkan kinerja perusahaan dalam suatu periode tertentu adalah laporan keuangan, laporan keuangan tidak hanya menggambarkan kinerja perusahaan dalam suatu periode tertentu tapi juga menggambar baik tidaknya kinerja manajemen yang ada di dalam perusahaan tersebut. Menurut Mary Parker Follet Dalam Handoko (2010:3) "manajemem adalah seni untuk menyelesaikan pekerjaan melalui orang lain". Dalam hal ini dapat di katakan laporan keuangan dapat mencerminkan kinerja manajemen dalam hal menyelesikan masalah melalui orang lain. Pemanfaatan kesempatan di masa mendatang serta meningkatkan nilai perusahaan hingga perusahaan tersebut memperoleh laba yang optimal dan dapat bertahan hingga tujuan perusahaan tersebut tercapai adalah tolak ukur dari manajemen yang baik. Mendirikan sebuah perusahaan memiliki tujuan utama yaitu memaksimalkan nilai perusahaan serta meningkatkan kesejahteraan para pemilik modal. Tolak ukur dari tercapai atau tidaknya tujuan tersebut antara lain adalah tingkat laba yang di peroleh perusahaan dalam suatu periode tertentu, yang didapat dari hasil usaha perusahaan ataupun dari pendapatan yang lainnya, yang pada akhirnya perusahaan memiliki dividend yang akan dibagikan kepada para pemegang saham atau para investor.

Devidend adalah distribusi yang bisa berbentuk kas, aktiva lain, surat atau bukti lain yang menyatakan hutang perusahaan kepada pemegang saham suatu perusahaan sebagai proporsi dari sejumlah saham yang dimilikioleh pemilik. Kebijakan deviden adalah keputusan apakah laba yang diperoleh perusahaan akan dibagikan ke pemegang saham sebagai deviden, atau akan ditahan dalam bentuk laba ditahan guna pembiayaan investasi dimasa mendatang (Sartono,2010)

Investor mempunyai tujuan utama dalam menanamkan dananya ke dalam perusahaan yaitu untuk mencari pendapatan atau tingkat pengembalian investasi (return) 
baik berupa pendapatan deviden maupun pendapatan dari selisih harga jual saham terhadap harga belinya (capital gain). Di sisi lain perusahaan yang akan membagikan deviden dihadapkan pada berbagai macam pertimbangan, yaitu perlunya menahan sebagian laba untuk re-investasi yang lebih menguntungkan, kebutuhan dana perusahaan, likuiditas perusahaan, sifat pemegang saham, target tertentu yang berhubungan dengan kebijakan deviden. Selain ittu perusahaan juga memiliki keinginan untuk menambah nilai dar perusahaan. Baik dari nilai saham yang ada dipasar maupun nilai perusahaan dimata masyarakat.

Tabel 1.1

Rasio Return On Asset, Current Ratio, Total Asset Turn Over, Quick Ratio, Earning Per Share, Devidend Payout Ratio Perusahaan Konstruksi di Bursa efek Tiongkok

\begin{tabular}{|c|c|c|c|c|c|c|}
\hline \multirow{2}{*}{ Perusahaan } & \multirow{2}{*}{ Tahun } & \multicolumn{5}{|c|}{ Rasio } \\
\hline & & ROA & CR & TATO & QR & EPS \\
\hline \multirow{5}{*}{ China Communication Contruction } & 2012 & 0,020 & 1,09 & 0,50 & 1,01 & 0,77 \\
\hline & 2013 & 0,018 & 1,02 & 0,49 & 0,93 & 0,78 \\
\hline & 2014 & 0,017 & 1,03 & 0,45 & 0,92 & 0,86 \\
\hline & 2015 & 0,022 & 1,96 & 0,55 & 1,82 & 0,96 \\
\hline & 2016 & 0,022 & 1,89 & 0,54 & 1,78 & 1,00 \\
\hline \multirow{5}{*}{ China Railway } & 2012 & 0,018 & 1,13 & 1,01 & 0,66 & 69,00 \\
\hline & 2013 & 0,019 & 1,21 & 1,06 & 0,69 & 84,00 \\
\hline & 2014 & 0,019 & 1,21 & 0,96 & 0,68 & 92,00 \\
\hline & 2015 & 0,019 & 1,19 & 0,86 & 0,68 & 98,00 \\
\hline & 2016 & 0,020 & 1,25 & 0,83 & 0,70 & 103,00 \\
\hline \multirow{5}{*}{ China Railway Group Limited } & 2012 & 0,015 & 1,19 & 0,85 & 1,07 & 0,354 \\
\hline & 2013 & 0,016 & 1,20 & 0,86 & 1,09 & 0,440 \\
\hline & 2014 & 0,016 & 1,16 & 0,86 & 1,06 & 0,482 \\
\hline & 2015 & 0,017 & 1,20 & 0,84 & 1,14 & 0,530 \\
\hline & 2016 & 0,017 & 1,17 & 0,84 & 1,12 & 0,517 \\
\hline \multirow{5}{*}{ China State Construction International Holding Limited } & 2012 & 0,057 & 1,62 & 0,53 & 1,60 & 57,32 \\
\hline & 2013 & 0,064 & 1,33 & 0,65 & 1,32 & 71,29 \\
\hline & 2014 & 0,061 & 1,10 & 0,62 & 1,09 & 88,75 \\
\hline & 2015 & 0,064 & 1,05 & 0,54 & 1,05 & 103,16 \\
\hline & 2016 & 0,058 & 1,01 & 0,54 & 1,01 & 119,80 \\
\hline
\end{tabular}

(Sumber: Website perusahan diolah sendiri, 2017)

Pada tabel diatas dapat diketahui bahwa ada perbedaan kebijakan dari perusahaan dan juga manajemen perusahaan untuk menggunakan aset perusahaan untuk mendapatkan penjualan, ataupun laba yang diperoleh untuk dibagikan kembali kepada pemegang saham. Maka peneliti tertarik untuk melakukan penelitian dengan judul "Pengaruh Return On Assets, Current Ratio, Total Asset Turn Over, Dan Quick Ratio Terhadap Earning Per Share (Studi Kasus Pada Perusahaan Jasa Konstruksi Yang Terdaftar Di Bursa Efek Tiongkok)". 


\section{B. Perumusan Masalah}

1. Bagaimana pengaruh return on asset, current ratio, total asset turnover, quick ratio secara parsial terhadap earning per share?

2. Bagaimana pengaruh return on asset, current ratio, total asset turnover, quick ratio secara simultan terhadap earning per share?

\section{Tujuan Penelitian}

1. Untuk mengetahui pengaruh return on asset, current ratio, total asset turnover, dan quick ratio secara parsial terhadap earning per share.

2. Untuk mengetahui pengaruh return on asset, current ratio, total asset turnover, dan quick ratio secara simultan terhadap earning per share.

\section{Landasan Teori}

\section{Pengertian Manajemen}

Menurut Malayu S.P (2003:2) manajemen adalah ilmu dan seni mengatur proses pemanfaatan sumber daya manusia dan sumber - sumber lainnya secara efektif dan efisien untuk mencapai suatu tujuan tertentu. Menurut Mary Parker Follet dalam Handoko (2010:3) manajemen adalah seni untuk menyelesaikan pekerjaan melalui orang lain. Artinya dalam kegiatan manajemen banyak orang yang akan terlibat di dalamnya dan tiap - tiap orang tersebut memiliki jobdesk - nya masing - masing baik dari pemasaran, sumber daya manusia, keuangan ataupun bagian operasi.

\section{Manajemen Keuangan}

Menurut Sartono (2008:6) manajemen keuangan dapat diartikan sebagai manajemen dana baik yang berkaitan dengan pengalokasian dana dalam bentuk investasi secara efektif maupun usaha pengumpulan dana untk pembiayaan investsi atau pembelanjaan secara efisien.

"Teori keuangan menjelaskan mengapa suatu fenomena dibidang keuangan terjadi dan mengapa keputusan keuangan tertentu perlu diambil dalam menghadapi persoalan keuangan tertentu" Suad Husnan dan Pudjiastuti (2006:4).

"Manajemen keuangan dapat diartikan sebagai manajemen dana baik yang berkaitan dengan pengalokasian dana dalam bentuk investasi secara efektif maupun usaha pengumpulan dana untuk pembiayaan invesasi atau untuk pembelanjaan secara efisien" Agus Sumantoro (2001:6).

\section{Laporan Keuangan}

"Laporan keuangan adalah hasil dari proses akuntansi yang dapat digunakan sebagai alat untuk berkomunikasi antara data keuangna atau aktivitas suatu perusahaan dengan pihak - pihak yang berkepentingan dengan data atau aktivitas perusahaan tersebut" Munawir (2010:2). "Suatu informasi yang menggambarkan kondisi suatu perusahaan, dimana selanjutnya itu akan menjadi suatu informasi yang menggambarkan tentang kinerja perusahaan" Irham Fahmi (2010:152). "laporan keuangan menggambarkan dampak keuangan dari transaksi dan peristiwa lain yang di klarifikasikan dalam beberapa kelompok besar menurut karakteristik ekonominya, kelompok besar ini merupakan unsur laporan keuangan. Unsur yang berkaitan langsung dengan pengukuran 
posisi keuangan adalah aktiva, kewajiban, dan ekuitas, sedangkan unsur yang berkaitan dengan pengukuran kinerja dalam laporan laba-rugi adalah penghasilan dan beban. Laporan perubahan posisi keuangan biasanya mencerminkan berbagai unsur neraca" Harmono (2009:22). Berdasarkan pendapat - pendapat diatas dapat disimpulkan bahwa hakikatnya laporan keuangan itu merupakan hasil akhir dari proses akuntansi. Laporan keuangan inilah yang menjadi bahan informasi bagi para pengguna laporan keuangan dan dapat juga digunakan sebagai dasar pengambilan keputusan. Disamping sebagai alat untuk pertanggung jawaban, laporan keuangan ini juga dapat menggambarkan indikasi kesuksesan suatu perusahaan dalam meningkatkan nilai perusahaan yang merupakan prinsip dasar dari didirikannya suatu perusahaan.

\section{Jasa Konstruksi}

Pada umumnya kegiatan konstruksi dimulai dari perendanaan yangdilakukan oleh konsultan perencana dan kemudian dilaksanakan oleh kontraktor konstruksi yang menjadi manajer proyek. Proyek sendiri merupakan sekumpulan aktivitas yang saling berhubungan. Ada titik awal dantitik akhir serta hasil tertentu. Proyek biasanya bersifat lintas fungsi organisasi sehingga membutuhkan bermacam keahlian dari berbagai perofesi dan organisasi. Proyek adalah aktivitas sementara dari personil, material, serta sarana untuk menjadikan atau mewujudkan sasaran proyek dalam kurun waktu tertentu yang kemudian berakhir (PT. Pembangunan Perumahan,2003). Proyek konstruksi yaitu satu rangkaian kegiatan yang dilakukan hanya satu kali saja umumnya dengan jangka waktu yang pendek (Ervianto,2005). Sehingga pengertian utuh dari jasa konstruksi adalah salah satu usaha dalam sektor ekonommi yang berhubungan dengansuatu perencanaan atu pelaksanaan dan pengawasan suatu kegiatan konstruksi untuk membentuk suatu bangungan atau bentuk fisik lainnya yang dalam pelaksanaan, penggunaan atau pemanfaatan bangunan tersebut menyangkut kepentingan dan keselamatan masayarakat atau pemakai bangunan tersebut, tertib pembangunannya serta kelestarian lingkungan hidup.

\section{Earning Per Share}

Menurut Zaki Baridwan (2004:443), yang dimaksud dengan laba per lembar saham adalah jumlah pendapatan yang diperoleh dalam satu periode tertentu untuk setiap jumlah saham yang beredar. Menurut Brigham \& Houston (2010:150), earning per share juga merupakan salah satu indikator rasio perusahaan yang penting. Earning per share menujukkan jumlah yayang rela dibayarkan oleh investor untuk setiap dolar laba yang dilaporkan. Laba per lembar saham dapat dicari dengan rumus sebagai berikut:

\section{E. Metodologi}

$$
\text { Laba Per Lembar Saham }=\frac{\text { Laba Saham Biasa }}{\text { Saham Biasa yang Beredar }}
$$

Penelitian ini dilakukan dengan metode deskriptif dengan pendekatan kuantitatif sedangkan metode pengolahan datanya adalah analisis regresi data panel dengan menggunakan software pengolah data statistik Eviews 9.0. Data yang diperoleh merupakan data sekunder berdasarkan laporan keuangan dalam kurun waktu 10 tahun yaitu dari tahun 2006-2016. Populasi yang digunakan dalam penelitian ini adalah seluruh perusahaan jasa konstruksi yang terdaftar di Bursa Efek Tiongkok tahun 2006 - 2016 sebanyak 10 perusahaan. Sampel yang digunakan dalam penelitian ini berdasarkan 
perusahaan jasa konstruksi yang terdaftar di Bursa Efek Tiongkok tahun 2006 - 2016 berturut-turut selama 10 tahun dari tahun 2006 sampai tahun 2016 sebanyak 8 bank. Sedangkan perusahaan jasa konstruksi yang menerbitkan laporan keuangan tahunan yaitu mulai tahun 2006 sampai tahun 2016 sebanyak 4 perusahaan. Dari hasil tersebut yang dapat digunakan dalam penelitian hanya 4 perusahaan yaitu, China Communication Construction Company Limited, China Railway Construction Corporation Limited, China Railway Group Limited, China State Construction International Limited.

\section{F. Hasil dan Pembahasan}

Metode analisis data yang digunakan dalam penelitian ini adalah metode statistik dengan menggunakan software pengolah data statistik Eviews 9.0

\section{Pengujian Model Regresi Data Panel}

\section{a. Uji Chow}

Uji Chow (F statistik) adalah pengujian yang dilakukan untuk mengetahui apakah model yang digunakan adalah common effect atau fixed effect yang paling tepat digunakan dalam mengestimasi data panel. Hipotesis dalam uji chow adalah

$\mathrm{HO}$ : Common Effect atau Pooled Least Square

$\mathrm{H} 1$ : Fixed effect Model

Dasar penolakan terhadap hipotesis diatas adalah dengan membandingkan perhitungan F-statistik dengan F-tabel. Perbandingan dipakai apabila hasil F-hitung lebih besar dari pada F-tabel maka $\mathrm{HO}$ ditolak yang berarti model yang paling tepat diginakan adalah Fexed Effect Model. Begitupun sebaliknya, jika F-hitung lebih kecil dari pada Ftabel maka HO di terima dan model yang digunakan adalah Common Effect Model (Widarjono, 2013).

\section{Tabel 1.2 Uji Chow ROA, CR, TATO, QR Terhadap EPS}

Redundant Fixed Effects Tests

Pool: Untitled

Test cross-section fixed effects

\begin{tabular}{lcrc}
\hline \hline Effects Test & Statistic & d.f. & Prob. \\
\hline \hline Cross-section F & 20.643000 & $(3,36)$ & 0.0000 \\
Cross-section Chi-square & 44.031847 & 3 & 0.0000 \\
\hline \hline
\end{tabular}

Cross-section fixed effects test equation:

Dependent Variable: EPS?

Method: Panel Least Squares

Date: 10/09/17 Time: 20:42

Sample: 20062016

Included observations: 11

Cross-sections included: 4

Total pool (balanced) observations: 44

\begin{tabular}{ccccc}
\hline \hline Variable & Coefficient & Std. Error & t-Statistic & Prob. \\
\hline \hline ROA? & -2.726650 & 0.738879 & -3.690254 & 0.0007 \\
CR? & -0.252382 & 0.101517 & -2.486109 & 0.0173
\end{tabular}




\begin{tabular}{crrrr} 
TATO? & -0.096931 & 0.042871 & -2.261017 & 0.0294 \\
QR? & 0.246815 & 0.087018 & 2.836366 & 0.0072 \\
C & 0.285499 & 0.078404 & 3.641361 & 0.0008 \\
\hline
\end{tabular}

\begin{tabular}{llll}
\hline \hline R-squared & 0.394962 & Mean dependent var & 0.080323 \\
Adjusted R-squared & 0.332907 & S.D. dependent var & 0.098811 \\
S.E. of regression & 0.080705 & Akaike info criterion & -2.089396 \\
Sum squared resid & 0.254016 & Schwarz criterion & -1.886648 \\
Log likelihood & 50.96672 & Hannan-Quinn criter.-2.014207 \\
F-statistic & 6.364685 & Durbin-Watson stat & 0.636207 \\
Prob(F-statistic) & 0.000483 & & \\
\hline \hline
\end{tabular}

(Sumber: Hasil Eviews 9/diolah sendiri, 2017)

Hasil uji Chow ROA, CR, TATO dan QR terhadap EPS pada tabel diatas dapat dilihat bahwa nilai probabilitas cross section adalah 0,00 . Dapat dikatakan bahwa $<0,05$ maka $\mathrm{H} 0$ ditolak, yang berarti menggunakan pendekatan fixed effect.

\section{Pengujian Hipotesis}

a. Pengujian Secara Parsial (Uji t)

\section{Tabel 2.1 Pengaruh ROA terhadap EPS}

\begin{tabular}{|c|c|c|c|c|}
\hline \multicolumn{5}{|c|}{$\begin{array}{l}\text { Dependent Variable: EPS? } \\
\text { Method: Pooled Least Squares } \\
\text { Date: } 11 / 15 / 17 \text { Time: } 05: 55 \\
\text { Sample: } 20062016 \\
\text { Included observations: } 11 \\
\text { Cross-sections included: } 4 \\
\text { Total pool (balanced) observations: } 44\end{array}$} \\
\hline Variable & Coefficient & Std. Error & t-Statistic & Prob. \\
\hline $\begin{array}{c}\text { ROA? } \\
\quad \mathrm{C}\end{array}$ & $\begin{array}{r}-1.784266 \\
0.133288\end{array}$ & $\begin{array}{l}0.728697 \\
0.025821\end{array}$ & $\begin{array}{r}-2.448571 \\
5.162074\end{array}$ & $\begin{array}{l}0.0186 \\
0.0000\end{array}$ \\
\hline $\begin{array}{l}\text { R-squared } \\
\text { Adjusted R-squared } \\
\text { S.E. of regression } \\
\text { Sum squared resid } \\
\text { Log likelihood } \\
\text { F-statistic } \\
\text { Prob(F-statistic) }\end{array}$ & $\begin{array}{l}0.124918 \\
0.104083 \\
0.093527 \\
0.367390 \\
42.84815 \\
5.995502 \\
0.018599\end{array}$ & \multicolumn{2}{|c|}{$\begin{array}{l}\text { Mean dependent var } \\
\text { S.D. dependent var } \\
\text { Akaike info criterion } \\
\text { Schwarz criterion } \\
\text { Hannan-Quinn criter. } \\
\text { Durbin-Watson stat }\end{array}$} & $\begin{array}{r}0.080323 \\
0.098811 \\
-1.856734 \\
-1.775634 \\
-1.826658 \\
0.307801\end{array}$ \\
\hline
\end{tabular}

(Sumber: Hasil Eviews 9/ diolah sendiri, 2017)

Berdasarkan tabel 2.1 Hasil pengujian analisis regresi data panel pada tabel 4.5 menunjukkan hasil t-hitung variabel return on asset adalah sebesar $-2,45$, tanda negatif berarti memiliki hubungan negatif atau berbanding terbalik, sementara $\mathrm{t}$-tabel dengan $\alpha=$ $5 \%$ dan $\mathrm{df}=\mathrm{n}-\mathrm{k}, \mathrm{df}=10$, maka t-tabel $(0,05 ; 10)=2,228$ (uji dua arah). Sehingga t-hitung lebih besar dari pada t-tabel $(2,45>2,23)$ jadi $\mathrm{HO}$ ditolak dan dapat disimpulkan bahwa variabel independen berpengaruh terbalik secara nyata terhadap variabel dependennya. Kemudian nilai probabilitas return on asset lebih kecil dari konstanta $(0.018<0,05)$ maka 
hasilnya signifikan, dapat dikatakan terdapat pengaruh dari variabel return on asset secara parsial terhadap variabel earning per share.

\section{Tabel 2.2 Pengaruh CR Terhadap EPS}

\begin{tabular}{|c|c|c|c|c|}
\hline $\begin{array}{l}\text { Dependent Variable: } \\
\text { Method: Pooled Leas } \\
\text { Date: } 11 / 17 / 17 \text { Tim } \\
\text { Sample: } 20062016 \\
\text { Included observation } \\
\text { Cross-sections incluc } \\
\text { Total pool (balanced) }\end{array}$ & $\begin{array}{l}\text { S? } \\
\text { quares } \\
6: 01 \\
11 \\
\text { : } 4 \\
\text { servations: }\end{array}$ & & & \\
\hline Variable & Coefficient & Std. Error & t-Statistic & Prob. \\
\hline $\begin{array}{c}\text { CR? } \\
\text { C }\end{array}$ & $\begin{array}{r}-0.090285 \\
0.111267\end{array}$ & $\begin{array}{l}0.046806 \\
0.021588\end{array}$ & $\begin{array}{r}-1.928909 \\
5.154066\end{array}$ & $\begin{array}{l}0.0605 \\
0.0000\end{array}$ \\
\hline -squared & 0.081379 & Mean depe & lent var & 0.080323 \\
\hline Adjusted R-squared & 0.059507 & S.D. depen & nt var & 0.098811 \\
\hline S.E. of regression & 0.095826 & Akaike info & iterion & -1.808178 \\
\hline Sum squared resid & 0.385670 & Schwarz cri & rion & -1.727078 \\
\hline Log likelihood & 41.77991 & Hannan-Qu & n criter. & -1.778102 \\
\hline F-statistic & 3.720688 & Durbin-Wat & n stat & 0.299161 \\
\hline Prob(F-statistic) & 0.060518 & & & \\
\hline
\end{tabular}

(Sumber: Hasil Eviews 9/ diolah sendiri, 2017)

Hasil pengujian analisis regresi data panel pada tabel 2.1 menunjukkan hasil thitung variabel current ratio adalah sebesar $-1,93$, tanda negatif berarti memiliki hubungan negatif atau berbanding terbalik, sementara t-tabel dengan $\alpha=5 \%$ dan $\mathrm{df}=\mathrm{n}-\mathrm{k}$, df $=10$, maka t-tabel $(0,05 ; 10)=2,228$ (uji dua arah). Sehingga t-hitung lebih kecil dari pada $t-$ tabel $(1,93<2,23)$ jadi HO diterima dan dapat disimpulkan bahwa variabel independen tidak berpengaruh terbalik secara nyata terhadap variabel dependennya. Kemudian nilai probabilitas current ratio lebih besar dari konstanta $(0.06>0,05)$ maka hasilnya tidak signifikan, dapat dikatakan tidak terdapat pengaruh dari variabel current ratio secara parsial terhadap variabel earning per share.

Tabel 2.3 Pengaruh TATO terhadap EPS

Dependent Variable: EPS?

Method: Pooled Least Squares

Date: 11/15/17 Time: 06:41

Sample: 20062016

Included observations: 11

Cross-sections included: 4

Total pool (balanced) observations: 44

\begin{tabular}{crrrr}
\hline \hline Variable & Coefficient & Std. Error & t-Statistic & Prob. \\
\hline \hline TATO? & -0.129476 & 0.046852 & -2.763531 & 0.0085 \\
C & 0.191034 & 0.042393 & 4.506287 & 0.0001 \\
\hline \hline
\end{tabular}


ISSN (online) : 2581-2777 \& ISSN (print) : 2581-2696

\begin{tabular}{lllr} 
R-squared & 0.153859 & Mean dependent var & 0.080323 \\
Adjusted R-squared & 0.133713 & S.D. dependent var & 0.098811 \\
S.E. of regression & 0.091968 & Akaike info criterion & -1.890365 \\
Sum squared resid & 0.355240 & Schwarz criterion & -1.809266 \\
Log likelihood & 43.58804 & Hannan-Quinn criter. & -1.860290 \\
F-statistic & 7.637102 & Durbin-Watson stat & 0.337606 \\
Prob(F-statistic) & 0.008452 & & \\
\hline
\end{tabular}

(Sumber: Hasil Eviews 9/ diolah sendiri, 2017)

Hasil pengujian analisis regresi data panel pada tabel 2.3 menunjukkan hasil thitung variabel total asset turnover adalah sebesar $-2,76$, tanda negatif berarti memiliki hubungan negatif atau berbanding terbalik, sementara t-tabel dengan $\alpha=5 \%$ dan $\mathrm{df}=\mathrm{n}$ $\mathrm{k}, \mathrm{df}=10$, maka t-tabel $(0,05 ; 10)=2,228$ (uji dua arah). Sehingga t-hitung lebih besar dari pada t-tabel $(2,76>2,23)$ jadi $\mathrm{HO}$ ditolak dan dapat disimpulkan bahwa variabel independen berpengaruh terbalik secara nyata terhadap variabel dependennya. Kemudian nilai probabilitas total asset turnover lebih kecil dari konstanta $(0.00<0,05)$ maka hasilnya signifikan, dapat dikatakan terdapat pengaruh dari variabel total asset turnover secara parsial terhadap variabel earning per share.

\section{Tabel 2.4 Pengaruh QR terhadap EPS}

Dependent Variable: EPS?

Method: Pooled Least Squares

Date: 11/17/17 Time: 05:47

Sample: 20062016

Included observations: 11

Cross-sections included: 4

Total pool (balanced) observations: 44

\begin{tabular}{lrllr}
\hline \hline \multicolumn{1}{c}{ Variable } & Coefficient & Std. Error & t-Statistic & Prob. \\
\hline \multicolumn{1}{c}{ QR? } & -0.388527 & 0.130452 & -2.978305 & 0.0048 \\
\multicolumn{1}{c}{ C } & 0.135435 & 0.023021 & 5.883003 & 0.0000 \\
\hline \hline R-squared & 0.174371 & Mean dependent var & 0.080323 \\
Adjusted R-squared & 0.154713 & S.D. dependent var & 0.098811 \\
S.E. of regression & 0.090846 & Akaike info criterion & -1.914906 \\
Sum squared resid & 0.346628 & Schwarz criterion & -1.833806 \\
Log likelihood & 44.12793 & Hannan-Quinn criter. & -1.884830 \\
F-statistic & 8.870301 & Durbin-Watson stat & 0.465492 \\
Prob(F-statistic) & 0.004798 & & & \\
\hline \hline
\end{tabular}

(Sumber: Hasil Eviews 9/ diolah sendiri, 2017)

Hasil pengujian analisis regresi data panel pada tabel 2.4 menunjukkan hasil thitung variabel quick ratio adalah sebesar $-2,97$, tanda negatif berarti memiliki hubungan negatif atau berbanding terbalik, sementara t-tabel dengan $\alpha=5 \%$ dan $d f=n-k, d f=10$, maka t-tabel $(0,05 ; 10)=2,228$ (uji dua arah). Sehingga t-hitung lebih besar dari pada ttabel $(2,97>2,23)$ jadi $\mathrm{HO}$ ditolak dan dapat disimpulkan bahwa variabel independen berpengaruh terbalik secara nyata terhadap variabel dependennya. Kemudian nilai probabilitas quick ratio lebih kecil dari konstanta $(0.00<0,05)$ maka hasilnya signifikan, 
dapat dikatakan terdapat pengaruh dari variabel return on asset secara parsial terhadap variabel earning per share.

\section{b. Pengujian secara simultan (Uji F)}

Menurut Priyatno (2012:55-56) "Uji F digunakan untuk menguji pengaruh variabel independen secara bersama-sama terhadap variabel dependen. Apabila nilai $F$ hitung $>F$ tabel, maka Ho ditolak dan dapat disimpulkan bahwa variabel independen secara simultan berpengaruh atau mempengaruhi variabel dependennya. Apabila $F$ hitung $<F$ tabel, maka Ho diterima dan dapat disimpulkan bahwa tidak ada variabel independen yang berpengaruh atau mempengaruhi variabel dependennya. Apabila nilai prob $F$ hitung (ditunjukkan pada prob) < dari tingkat kesalahan (a) sebesar 0,05 maka dapat dikatakan bahwa variabel independen berpengaruh signifikan terhadap variabel dependen".

\section{Tabel 2.5 Pengaruh ROA, CR, TATO, QR Terhadap EPS}

\begin{tabular}{|c|c|c|c|c|}
\hline \multicolumn{5}{|c|}{$\begin{array}{l}\text { Dependent Variable: EPS? } \\
\text { Method: Pooled Least Squares } \\
\text { Date: } 10 / 10 / 17 \text { Time: } 05: 54 \\
\text { Sample: } 20062016 \\
\text { Included observations: } 11 \\
\text { Cross-sections included: } 4 \\
\text { Total pool (balanced) observations: } 44\end{array}$} \\
\hline Variable & Coefficient & Std. Error & t-Statistic & Prob. \\
\hline ROA? & -2.726650 & 0.738879 & -3.690254 & 0.0007 \\
\hline CR? & -0.252382 & 0.101517 & -2.486109 & 0.0173 \\
\hline TATO? & -0.096931 & 0.042871 & -2.261017 & 0.0294 \\
\hline QR? & 0.246815 & 0.087018 & 2.836366 & 0.0072 \\
\hline C & 0.285499 & 0.078404 & 3.641361 & 0.0008 \\
\hline R-squared & 0.394962 & \multicolumn{2}{|c|}{ Mean dependent var } & 0.080323 \\
\hline Adjusted R-squared & 0.332907 & \multirow{2}{*}{\multicolumn{2}{|c|}{ S.D. dependent var }} & 0.098811 \\
\hline S.E. of regression & 0.080705 & & & -2.089396 \\
\hline Sum squared resid & 0.254016 & \multirow{2}{*}{\multicolumn{2}{|c|}{ Schwarz criterion }} & -1.886648 \\
\hline Log likelihood & 50.96672 & & & -2.014207 \\
\hline F-statistic & 6.364685 & \multicolumn{2}{|c|}{$\begin{array}{l}\text { Hannan-Quinn criter. } \\
\text { Durbin-Watson stat }\end{array}$} & 0.636207 \\
\hline Prob(F-statistic) & 0.000483 & & & \\
\hline
\end{tabular}

(Sumber: Hasil Eviews 9/ diolah sendiri, 2017)

Berdasarkan tabel 2.5 pengujian analisis regresi data panel menunjukkan hasil dari f-hitung variabel return on assets, current ratio, total assets turnover, dan quick ratio secara simultan sebesar 6,36 . Sementara t-tabel dengan $\alpha=5 \%$ dan df1 $=k-1=4$, df2 $=$ $\mathrm{n}-\mathrm{k}=6$, maka f-tabel $(0,05 ; 4 ; 6)=4,53$. Sehingga $\mathrm{f}$-hitung lebih besar dari pada $\mathrm{f}$ tabel $(6,36>4,53)$ jadi HO ditolak, dan dapat disimpulkan bahwa variabel return on assets, current ratio, total assets turnover, dan quick ratio secara bersama - sama memiliki pengaruh yang berbanding lurus secara nyata terhadap variabel earning per share. Kemudian nilai probabilitas yang lebih kecil dari pada nilai konstanta $(0,00<0,05)$ maka hasilnya signifikan, yang berarti terdapat pengaruh yang nyata dari variabel return on 
assets, current ratio, total assets turnover, dan quick ratio terhadap earning per share secara simultan.

\section{c. Koefisien Determinasi (Adjusted R-Square)}

Berdasarkan hasil penghitungan menggunakan software eviews 9 pada tabel 2.5, nilai dari $R$-squared adalah 0,40 . Hal ini menunjukkan bahwa presentase sumbangan pengaruh variabel independen terhadap variabel dependen adalah sebesar $40 \%$ yang dapat diartikan bahwa variabel independen yang digunakan dalam model mampu menjelaskan sebesar $40 \%$ terhadap variabel dependennya. Sedangkan sisanya $60 \%$ dipengaruhi faktor lain di luar model regresi tersebut. Dari nilai koefisiensi determinasi $\left(R^{2}\right)$ 0,395, maka dapat diketahui bahwa nilai keofisien korelasi $(R)$ adalah 0,628 yang menunjukkan hubungan kuat, karena berada di interval koefisiensi 0,600-0,799.

\section{d. Persamaan Model Regresi}

Berdasarkan hasil penghitungan menggunakan Eviews 9 pada tabel 2.5, maka diperoleh persamaan model regresi antara variabel return on assets, current ratio, total assets turnover, dan quick ratio sebagai berikut:

$$
Y=0,29-2,73 X 1-0,25 X 2-0,096 X 3+0,25 X 4+€ i t
$$

Dari persamaan diatas dapat dijelaskan bahwa:

1. Konstanta sebesar 0,29 menunjukkan bahwa jika variabel independen (return on assets, current ratio, total assets turnover, dan quick ratio) pada observasi ke-i dan periode ke-t adalah nol, maka nilai earning per share adalah sebesar 0,29.

2. Koefisien regresi sebesar 2,73 menunjukkan bahwa jika nilai return on asset pada observasi ke-i dan periode ke-t naik sebesar 1 akan menurunkan nilai earning per share pada observasi ke-i dan periode ke-t sebesar 2,73.

3. Koefisien regresi sebesar 0,25 menunjukkan bahwa jika nilai current ratio pada observasi ke-i dan periode ke-t naik sebesar 1 akan menurunkan nilai earning per share pada observasi ke-i dan periode ke-t sebesar 0,25.

4. Koefisien regresi sebesar 0,25 menunjukkan bahwa jika nilai quick ratio pada observasi ke-i dan periode ke-t naik sebesar 1 akan meningkatkan nilai earning 5per share pada observasi ke-i dan periode ke-t sebesar 0,25.

\section{G. Kesimpulan}

Berdasarkan hasil pengujian dan analisis yang telah dilakukan, maka dapat disimpulkan sebagai berikut:

1. Hasil penelitian menyatakan bahwa terdapat pengaruh yang signifikan yang rendah antara return on asset terhadap earning per share. Variabel return on asset mempengaruhi variabel earning per share sebesar $10,4 \%$, sedangkan sisanya $89,6 \%$ dipengaruhi oleh faktor lain.

2. Hasil penelitian menyatakan bahwa tidak terdapat terdapat pengaruh yang signifikan antara current ratio terhadap earning per share. Variabel current ratio mempengaruhi earning per share sebesar 5,9\%, sedangkan sisanya $94,1 \%$ dipengaruhi faktor lain. 
3. Hasil penelitian menyatakan bahwa terdapat pengaruh yang signifikan antara total asset turnover terhadap earning per share. Variabel total asset turn over mempengaruhi variabel earning per share sebesar $13,4 \%$ sedangkan sisanya $86,6 \%$ dipengaruhi faktor lain.

4. Hasil penelitian menyatakan bahwa terdapat pengaruh yang signifikan antara quick ratio terhadap earning per share. Variabel quick ratio mempengaruhi variabel earning per share sebesar $15,5 \%$, sedangkan sisanya $84,5 \%$ dipengaruhi faktor lain.

5. Berdasarkan hasil penelitian, maka peneliti dapat menyimpulkan bahwa return on assets, current ratio, total assets turnover, dan quick ratio secara simultan memiliki pengaruh signifikan sebesar $40 \%$ terhadap earning per share, sedangkan sebanyak $60 \%$ di pengaruhi oleh faktor lain diluar penelitian ini.

\section{H. Daftar Pustaka}

Abdul, Halim,"Analisis Investasi", Edisi kedua, Salemba Empat, Jakarta, 2005

Agus, Sartono, “Manajemen Keuangan”, Edisi Ketiga, Cetakan Pertama, BPFE, Yogyakarta, 2002

Agus Sartono , “Manajemen Keuangan Teori Dan Aplikasi”, Cetakan Pertama, BPFE, Yogyakarta, 2012

Astuti, Dewi, “Manajemen Keuangan Perusahaan”, Gahlia Indonesia, Jakarta, 2004

Baridwan, Zaki, “Intermediate Accounting”, Edisi Kedelapan, BPFE, Yogyakarta, 2004

Brigham, EugenenF., \& Houston, Joel F. “Dasar - Dasar Manajemen Keuangan”, Edisi Ke 10, Salemba Empat, Jakarta, 2010

Dwi, Prastowo, “Analisis Laporan Keuangan”, Edisi Ketiga, Cetakan Pertama, UPP STIM YKPN, Yogyakarta, 2011

Ervianto, W, “Manajemen Proyek Konstruksi”, Edisi Revisi, Andi, Yogyakarta, 2005

Hani Handoko, "Manajemen Personalia \& Sumber daya Manusia", Edisi kedua, BPFE UGM Yogyakarta, 2010

Hasibuan, S.P. Malayu, “Manajemen Sumber Daya Manusia”, PT Bumi Aksara, Jakarta, 2010

Harmono, "Manajemen Keuangan Berbasis Balanced Scorecard (Pendekatan Teori, Kasus, dan Riset Bisnis)", Bumi Aksara, Jakarta, 2009

Irham Fahmi, “ Manajemen Kinerja”, Cetakan Pertama, CV. Alfabeta, Bandung, 2010

Kasmir, "Pengantar Manajemen Keuangan", Edisi Pertama, Cetakan Kedua, Kencana Prenada Media Group, Jakarta, 2010

Munawir, S, “Analisa Laporan Keuangan", Edisi Keempat, Cetakan Kelima Belas, Liberty, Yogyakarta, 2010 
Mamduh M. Hanafi, Abdul Malik, "Analisis Laporan Keuangan" Penerbit Unit Penerbit dan Percetakan Sekolah Tinggi Ilmu Manajemen YKPN, Yogyakarta,2009

Martono, dan D. Agus Harjito, “Manajemen Keuangan”, Ekonisia, Yogyakarta, 2005

Manahan, P. Tampubolon, “Manjemen Keuangan”, Ghalia Indonesia, Jakarta, 2005

Moh, Nazir, "Metode Penelitian", Ghalia, Indonesia, 2011

Paul D. Kimmel, Jerry J. Weygandt dan Donald E. Kieso (2011:584

Rusidin, “Pasar Modal”, Cetakan Ketiga, Alfabeta, Bandung, 2008

Suad Husnan dan Eny Pudjiastuti, "Dasar - Dasar Manajemen Keuangan" Edisi Kelima, UPP STIM YKPN, Yogyakarta, 2008

Sartono, Agus, “Ringkasan Teori Manajemen Keuangan”, BPFE UGM, Yogyakarta, 2003

Sugiyono,"Metode Penelitian Bisnis", Penerbit : Alfabeta, Bandung, 2010.

Sugiyono,"Metode Penelitian Kuantitatif Kualitatif dan $R$ \& D", Cetakan Keempat, Alfabeta,CV,Bandung,2011.

Sudjana,"Metode Statistika”, PT Gramedia Pustaka Utama, Bandung, 2000

Setyo Tri Wahyudi (2016:69).

Sunardi, N. (2019). Kinerja Perusahan Pendekatan Du Pont System Terhadap Harga Dan Return Saham (Perusahaan yang tergabung dalam Industri Real Estate dan Properti yang terdaftar di Bursa Efek Indonesia Tahun 2011-2017). JIMF (Jurnal IImiah Manajemen Forkamma), 1(3).

Sunardi, N. (2019, January). Relevansi Struktur Kepemilikan Tentang Profitabilitas Dan Nilai Perusahaan (Studi pada Industri Manufaktur yang Terdaftar di Bursa Efek Indonesia Periode 2010-2017). In Proceedings (Vol. 1, No. 1).

Sunardi, N., \& Permana, R. D. I. (2019). Faktor-Faktor Yang Mempengaruhi Harga Saham Dan Dampaknya Pada Nilai Perusahaan (Studi Kasus pada Perusahaan Sub Sektor Pertambangan Minyak dan Gas Bumi yang Terdaftar di Bursa Efek Indonesia Tahun 2013-2017). JIMF (Jurnal IImiah Manajemen Forkamma), 2(1).

Sunardi, N. (2017). Pengaruh Profitabilitas, Firm Size, Risiko Bisnis, Asset Growth, Leverage, Kebijakan Dividen Terhadap Institutional Ownership (Perusahaan Property \& Real Estate yang terdaftar di Bursa Efek Indonesia Tahun 20112014). INOVASI, 2(2).

Warsono, “Manajemen Keuangan”, Edisi Ke 3, Erlangga, Jakarta, 2003 